\title{
PELATIHAN PEMBUATAN DAN PENGURUSAN MEREK DAGANG (HKI) BAGI PELAKU USAHA KECIL DAN MENENGAH DI KOTA PADANG
}

\author{
RosyeniRasyid ${ }^{1}$ \\ MuthiaRoza Linda ${ }^{2}$ \\ YolandafitriZulvia ${ }^{3}$ \\ Riza Yonita ${ }^{*}$ \\ Deni Suwandhani ${ }^{5}$ \\ 1,2,3 Jurusan Manajemen, FakultasEkonomi Universitas Negeri Padang, Padang, Indonesia \\ 4*,5Prodi Sistem Informasi, Fakultas Ilmu komputer, Universitas Putra Indonesia YPTK Padang \\ rosyenirasyid@gmail.com ${ }^{1^{*}}$ \\ muthia@fe.unp.ac.id ${ }^{2}$ \\ yolandafitri86@gmail.com $\left.{ }^{3}\right)$ \\ rizayonitaupi@gmail.com $^{4 *}$ \\ denisuwandhani88@gmail.com ${ }^{5}$
}

Kata Kunci:

[MerekDagang,

UMKM,HAKI]
Abstrak: Adapun latar belakang adanya pelaksanaan pengabdianmasyarakatinikurangnyapemahaman dan pengetahuanpara pengusaha UMKM untukmendaftarkan merek dagang dan jasanya. Adapun metode pelaksanaan pada pengabdianmasyrakatiniadalahCeramahntukmenyampaikanteori dan konsep-konsep yang sangat prinsip dan penting untuk dimengerti serta dikuasai oleh peserta pelatihan. Praktekdalampembuatan dan pengurusan merek dagang. Hasilnya, Pelaku usaha yang ditunjuk untuk mengikuti pelatihan mengetahui dan memahami apa itu HKI dan bagaimana peranan HKI, 2. Peserta mengetahui dan memahami apa saja yang harus disiapkan agar proses pengajuan merek dagang. Melalui pelaksanaan PKM inipesertadiharapkanmampumemahami tentang pentingnya merek dagang dan bagaimana cara pengurusan merek dagang.

Published by:

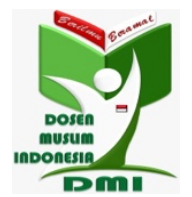

Copyright (C) 2021 The Author(s)

Thisarticleislicensedunder CC BY 4.0 License (cc) $\mathrm{Br}$ 


\section{Pendahuluan}

Pemberdayaan ekonomi merupakan suatu komitmen politik untuk mengubah paradigma ekonomi konglomerasi secara bertahap dengan menumbuhkan kegiatan ekonomi lapis bawah (Zurkanain 2006). Tujuan pemberdayaan usaha kecil yaitu untuk menumbuhkan dan meningkatkan kemampuan mereka agar mandiri serta berkembang menjadi usaha menengah. Salah satunya adalah koperasi, Koperasia dalah badan usaha yang beranggotakan orang atau badan hukum yang berlandaskan pada asas kekeluargaan dan demokrasi ekonomi. Kegiatan usaha koperasi merupakan penjabaran dari UUD 1945 pasal 33 ayat (1). Dengan adanya penjelasan UUD 1945 Pasal 33 ayat (1) koperasi berkedudukan sebagai soko guru perekonomian nasional dan sebagaibagian yang tidak terpisahkan dalam system perekonomian nasional. Sebagai salah satu pelaku ekonomi, koperasi merupakan organisasi ekonomi yang berusaha menggerakkan potensi sumber daya ekonomi demi memajukan kesejahteraan anggota. Karena sumber daya ekonomi tersebut terbatas, dan dalam mengembangkan koperasi harus mengutamakan kepentingan anggota, maka koperasi harus mampu bekerja seefisien mungkin dan mengikuti prinsip-prinsip koperasi dan kaidah-kaidah ekonomi.

Dunia wirausaha merupakan salah satu refleksi embrio bagi setiap daerah dalam menghasilkan nilai tambah yang lebih baik dengan mensikapi keragaman ketersediaan potensi sumber daya atas produk ataupun jasa yang dihasilkan khususnya dalam memediasi intensitas dan kualitas pertumbuhan perekonomian daerah. Kemampuan suatu daerah dalam memediasi dan memfasilitas dunia wirausaha secara relevan diharapkan mampu mendorong pelaku bisnis untuk lebih maksimal dalam mengembangkan sektor bisnis yang ada menjadi lebih potensial bagi pertumbuhan perekonomian daerah. Lebih lanjut, refleksi peranan dunia wirausahadalam proses pertumbuhan perekonomian yang lebih baik secara relative terlihat pada intensitas keberadaan usaha kecil menengah, hal ini di ungkapkan oleh M.Tohar (2000) mendefinisikan perusahaan kecil " merupakan kegiatan ekonomi rakyat yang bersekala kecil dan memenuhi kekeayaan bersih dan hasil penjualan tahunan serta kepemilikan sebagai mana di atur oleh undang-undang". Memahami pada masing - masing sektor usaha yang ada secara umum diharapkan mampu berkembang dan memberikan kontribusi positif terhadap peningkatan jumlah Product Domestic Bruto (PDB), dan secara luas dalam proses peningkatan kesejahteraan dan perkonomian daerah dimasa akan datang. Kemampuan eksistensi keberadaan usaha kecil menengah dan sejenisnya merupakan faktor kunci dalam memahami proses aktifitas usaha yang lebih efisien terhadap efektifitas pencapaian tujuan usaha yang lebih maksimal dalam jangka panjang.

Menghadapi pasar bebas ASEAN saat ini, peranan dari merek dagang suatu produk sangatlah penting, Menurut Imam, dkk (2005) fungsi merek adalah sebagai sebagai tanda pembeda (pengenal), melindungi masyarakat konsumen, menjaga dan mengamankan kepentingan produsen, memberi gengsi kaena reputasi dan jaminan kualitas. Adanya Masyarakat Ekonomi ASEAN (MEA) maka akan terjadi banjir produk dan jasa di wilayah Asia Tenggara tanpa hambatan berat. Ancaman paling besar MEA terkait hak cipta akan dialami oleh pelaku Usaha Kecil Menengah (UKM) dan industri kreatif kecil. Sebab, industri kecil masih mengalami masa terlena dan masih awam dengan pentingnya pendaftaran HAKI atas produk dan mereknya. 
Masih rendahnya kesadaran para pengusaha UMKM untuk mendaftarkan merek dagang dan jasanya ini sangat disayangkan sekali, karena pada akhirnya produk-produk usaha UMKM ini sering kali dijual tanpa merek dan produknya diperjual belikan kembali dengan menggunakan merek dagang dan jasa pihak ke tiga. Hal ini tentu sangat merugikan bagi para pengusaha UKM itu sendiri karena mereka tidak mendapatkan nilai tambah dari produk yang mereka perjual belikan.

Pendaftaran merek merupakan salah satu upaya yang dapat dilakukan agar pemegang merek mendapat perlindungan hukum, siapa yang pertama mendaftarkan dialah yang berhak atas merek dan dialah yang secara eksklusif dapat memakai merek tersebut. Seperti contohnya pada produk keripik balado, yang dikenal sebagai makanan khas Kota Padang, masih banyaknya jumlah pelakuusahakeripikbalado di Kota Padang yang belum mendaftarkan merek dagangnya yaitu sebanyak $75 \%$, mereka hanya mempunyai suat izin usaha (SIU). Pengusaha keripik balado di Kota Padang yang sudah memiliki sertifikat merek dagangnya yaitu sebanyak 12,5\% seperti Sutan Pangeran, Christine Hakim, Mahkota sedangkan 12,5\% lagi sertifikat merek dagangnya masih dalam proses seperti Shirly, Pusako dan Rohana Kudus. Hal ini sangat ironis apabila dibandingkan dengan jumlah pelakuusahakeripikbalado yang ada di Kota Padang tetapi dalam hal ini masih sedikit kemauan dari pelaku usaha yang ada untuk mendaftarkan merek dagangnya.

Pendaftaran Merek merupakan salah satu cara yang dapat dilakukan agar pemegang merek mendapat perlindungan hukum dari pemerintah. Merek Dagang di Kota Padang. Salah satu kendala yang dihadapi dalam pendaftaran merek dagang yaitu proses pendaftaran merek memakan waktu yang relatif panjang. Selain itulamanyapemeriksaan substantive juga sebaiknya tidak perlu terlalu lama Sedangkan yang menjadi penyebab utama minimnya pendaftaran merek dagang dikalangan pelaku usaha dikarenakan kurangnya pengetahuan masyarakat mengenai pentingnya merek dagang tersebut (kompas). Pelaku usaha beranggapan bahwa mereka telah mendaftarkan merek dagangnya yaitu dengan adanya Surat Izin Usaha (SIU), Surat Izin Tempat Usaha (SITU). Sebagian besar pelaku usaha tidak mengetahui atau membedakan yang mana sertifikat merek dagang dan mana yang surat izin usaha karena mereka lebih cenderung mempersamakan keduanya. Dalam hal ini pemerintah harus bekerja keras mensosialisasikan pentingnya pendaftaran merek sebab jika tidak ada tindakan yang dilakukan pemerintah maka usaha-usaha yang ada tidak dapat bersaing di dunia perekonomian dengan produk-produk yang telah memiliki merek.

Tujuan yang ingin dicapai dari kegiatan pengabdian pada masyarakat ini adalah:

1. Membekali pelaku usaha kecil menengah tentang persyaratan apa sajakah yang harus dipenuhi oleh pelaku usaha dalam mendaftarkan Merek Dagangnya di Kota Padang

2. Membekali pelaku usaha kecil menengah tentang pentingnya Merek Dagang dalam menghadapi persaingan yang semakin kompetitif dalam MEA.

3. Membekali pelaku usaha kecil menengah dalam menghadapi kendala-kendala dalam pendaftaran Merek Dagang di Kota Padang

\section{MetodePelaksanaan}

Mitra dalampelaksanaanpkmini adalah pelaku usaha kecil dan menengah di Kota Padang, dilaksanakan di ruang perkuliahan M.406 Fakultas Ekonomi Universitas Negeri 
Padang dengan jumlah peserta sebanyak 30 orang. Kegiatan dilaksanakan pada hari Sabtu tanggal 12 November 2016 yang dimulai pukul 08.00 WIB sampai dengan pukul 16.00 WIB. Berikut adalah peta lokasi pelaksanaan kegiatan PKM.

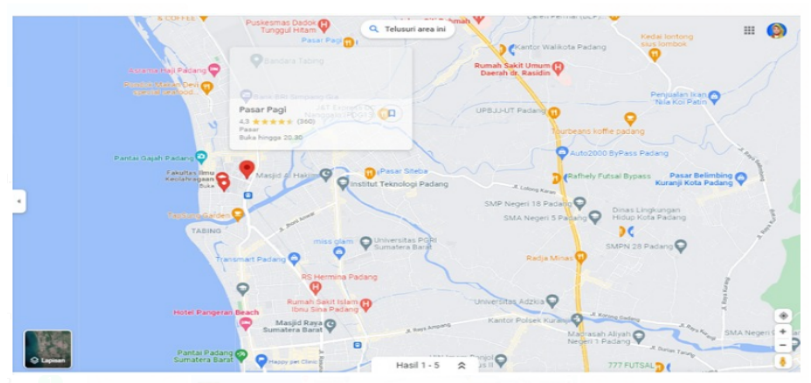

Gambar 1. Lokasi KegiatanPengabdian Masyarakat (Universitas Negeri Padang)

Khalayak sasaran kegiatan pelatihan ini para pelaku usaha kecil menengah yang belum memiliki merek dagang yang berdomisili di Kota Padang. Khalayak sasaran ini dipilih karena tujuan dari pengabdian ini memang diperuntukkan bagi pelaku usaha yang belum memiliki merek dagang untuk memperkenalkan kepada mereka tentang merek dagang dan pentingnya merek dagang dalam kegiatan usaha saat ini. Jika sasaran ini berhasil dalam pengenalan merek dagang dan menghasilkan merek dagang untuk usaha mereka, maka akan dilakukan pelatihan bagi pelaku-pelaku usaha lainnya yang belummendapatkanpelatihantentangmerekdagang.

Untuk mencapai tujuan kegiatan pengabdian sebagaimana yang telah dinyatakan di atas, makametodekegiatan yang digunakanmeliputi:

1. Ceramah bervariasi

Metode ini dipilih untuk menyampaikan teori dan konsep-konsep yang sangat prinsip dan penting untuk dimengerti serta dikuasai oleh peserta pelatihan. Materi yang diberikan meliputi: Pasar MEA, Hak Merek Dagang, Cara Menciptakan Merek Dagang, Promosi produk melalui merek dagang, dan Prosedur Pengurusan Merek Dagang.

2. Praktek dalam pembuatan dan pengurusan merek dagang..

\section{Hasil dan Pembahasan}

Adapun hasil pelaksanaan kegiatan PKM ini Melalui Pelatihan Pembuatan Dan Pengurusan Merek Dagang (HKI) Bagi Pelaku Usaha Kecil Dan Menengah Di Kota Padang, makadiperolehhasilsebagaiberikut:

Tabel 1. Hasil kegiatan pelatihan dan pengurusan Merek Dagang HKI bagi pelaku usahakecil menengah di kota Padang

\begin{tabular}{|c|c|c|c|}
\hline No & Kegiatan & Respon & Keterangan \\
\hline 1 & Pengenalan tentang HKI & Sangat Bagus & $\begin{array}{l}\text { Peserta mengetahui dan } \\
\text { memahami apa itu HKI dan } \\
\text { bagaimana peranan HKI dalam } \\
\text { memberikan Keunggulan } \\
\text { kompetitif akan produk yang } \\
\text { mereka hasilkan. }\end{array}$ \\
\hline 2 & Pengenalan Pasar MEA & Sangat Bagus & $\begin{array}{l}\text { Peserta mendapatkan pengetahuan } \\
\text { bahwa saat ini dalam pasar, } \\
\text { barang-barang yang }\end{array}$ \\
\hline
\end{tabular}




\begin{tabular}{|c|c|c|c|}
\hline & & & $\begin{array}{l}\text { diperdagangkan berasal dari } \\
\text { berbagai Negara karena adanya } \\
\text { kemudahan-kemudahan yang } \\
\text { diberikan bagi Negara anggota } \\
\text { untuk masuk ke masing-masing } \\
\text { pasar disetiap Negara anggota }\end{array}$ \\
\hline 3 & $\begin{array}{l}\text { Pengenalan Merek } \\
\text { Dagang }\end{array}$ & Sangat bagus & $\begin{array}{l}\text { Peserta mengetahui apa yang } \\
\text { dimaksud dengan merek dagang tu } \\
\text { sendiri dan apa bedanya dengan } \\
\text { hak kekayanintellektual lainnya }\end{array}$ \\
\hline 4 & $\begin{array}{l}\text { Pengurusan Merek } \\
\text { Dagang }\end{array}$ & Sangat Bagus & $\begin{array}{l}\text { Peserta mengetahui dan } \\
\text { memahami apa saja yang harus } \\
\text { disiapkan agar proses pengajuan } \\
\text { merek dagang tidak menghadapi } \\
\text { masalah }\end{array}$ \\
\hline
\end{tabular}

Kegiatan pengabdian yang dilaksanakan di ruang perkuliahan Fakultas Ekonomi Universitas Negeri Padang dengan jumlah peserta sebanyak 30 orang. Kegiatan dilaksanakan pada hari Sabtu tanggal 12 November 2016 yang dimulai pukul 08.00 WIB sampai dengan pukul $16.00 \mathrm{WIB}$.

Kegiatan pengabdian dibagi atas dua sesi, sesi pertama dimulai dari jam 8.30 pagi hingga jam 12.30 siang dengan materi tentang pengenalan Hak Kekayaan Intelektual (HKI) dan MEA yang kemudian dilanjutkan dengan diskusi tanya jawab dengan para pemateri. Sesi kedua dimulai jam 13.30 siang hingga jam 16.00 sore dengan materi tentang merek dagang dan bagaimana prosedur pengisian formulir pengajuan merek dagang.

Pada awal kegiatan dilaksanakan, peserta pelatihan diberikan penjelasan tentang apa itu yang dimaksud denganHakKekayaanIntellektual (HKI) dan terdiri dari apa saja HKI itu serta apa perbedaan masing-masingnya, kemudian dilanjutkan dengan penjelasan mengenai Masyarakat Ekonomi ASEAN (MEA). Setelah pemberian materi, dilanjutkan dengan tanya jawab, agar peserta dapat lebih memahami arti pentingnya HKI dalam dunia uaha, baikitusebagai promosi maupun untuk melindungi produk dari pesaing di pasar yang telah mengglobal saat ini, terutama dalam menghadapi MEA. Dan dengan tanya jawab, hal-hal yang meragukan dan tidak dipahami oleh peserta dapat mereka tanyakan langsung kepada pemateri. Melalui materi pada sesi pertama ini, diharapkan peserta dapat bertambah wawasan dan pengetahuannya tentang pentingnya merek dagang dalam dunia usaha dalam menghadapi pasar MEA.

Selanjutnya sesi kedua, peserta diberi materi tentang merek dagang. Pada sesi ini, dijelaskan arti pentingnya merek dagang bagi produk yang kita hasilkan terutama produk yang masih bersifat industri rumahan dan dipasarkansecara local dalam pasar yang sudah mengglobal saat ini. Peserta dibekali jenis-jenis HKI sehinggamereka tau yang mana yang akan mereka daftarkansebagaihakkekayan intellectual atasusaha mereka dan bagaimana cara pengajuan untuk pendaftaran merek dagang dan apa saja yang diperlukan dalam pengajuan merek dagang, apa keuntungan bagi mereka dan produk yang dihasilkan jika peserta mengurus HKI pada produk yang mereka hasilkan. Minat peserta akan materi ini sangat tinggi, terutama dalam hal mengenai bagaiamana 
sebaiknya dalam pembuatan merek tersebut. Apakah merek dalam bentuk nama, angka atau simbol yang lebih menarik bagiproduk-produk yang mereka hasilkan.

Untuk mengukur hasil dari pelatihan ini, panitia pelaksana melalui organisasi PERWIRA Kota Padang Panjang akan memantau peserta pelatihan apakah mereka telah merancang model untuk merek usaha mereka dan telah mengirimkan formulir pendaftaran merek kepada instansi terkait yang mengurus tentang merek tersebut. Berdasarkan informasi yang diperoleh dari PERWIRA, beberapa peserta pelatihan telah merancang merek yang akan mereka gunakan pada produk yang mereka jual yang selanjutnya akan mereka daftarkan HKI, oleh karena itu mereka rajin ke dinas untuk konsultasi. Bahkan ada dari peserta pelatihan yang telah memiliki hak paten berupa sulam benang emas. Para peserta pelatihan termotivasi untuk menciptakan suatu merek yang dilindungi sebagai Hak Kekayaan Intelektual dari usaha mereka.

Dalam kegiatan ini tim pelaksana melakukan evaluasi terhadap pengetahuan peserta dengan menggunakan konsep tanya jawab dan diskusi terbuka. Dari proses diskusi dan tanya jawab tersebut, diharapkan dapat terlihat pemahaman dan pengetahuan peserta tentang materi yang diberikan

\section{Kesimpulan}

Dari kegiatan pengabdian kepada masyarakat yang berjudul Pelatihan Pembuatan Dan Pengurusan Merek Dagang (HKI) Bagi Pelaku Usaha Kecil Dan Menengah Di Kota Padang dapat diketahui sebelum diadakannya pelatihan masih banyak peserta yang belum mengetahui tentang pentingnya merek dagang dan bagaimana cara pengurusan merek dagang. Setelah diadakannya kegiatan pengabdian ini diharapkan peserta dapat mengenal secara lebih mendalam tentang merek dagang, pentingnya merek dagang bagi usaha dan mengetahui bagaimana cara pengurusan merek dagang.

\section{UcapanTerimakasih}

Terima kasih atas LPPM Universitas Negri Padang yang mana telah mendanai pelaksanaan ini dan juga kerja sama dengan dosen Unirversitas Putra Indonesia serta semua pihak yang telak mendukung terlaksananya kegiatan PKM ini.

\section{Referensi}

Imam Sjahputra Tunggal, dkk. 2005. Hukum Merek di Indonesia. Harvarindo, Jakarta

M.Tohar. 2000. Membuka Usaha Kecil. Jakarat: Kanisius

Zulkarnain. 2006. Kewirausahaan Strategi Pemberdayaan Usaha Kecil Menengah Dan Penduduk Miskin, Penerbit Adi Cipta Karya Nusa, Yogyakarta

Undang-undang Nomor 15 Tahun 2001

Undang-Undang Nomor 20 Tahun 2008

http://www.kompasiana.com/aguscandra/pentingnya-pendaftaran-merek-bagipengusaha-umkm_55203a2ba333112445b659fb 